\title{
FREEDOM AND EQUALITY IN A PLURALIST SOCIETY: AN EXPLANATION AND DEFENCE OF THE PUBLIC REASON VIEW
}

\section{Elvio Baccarini}

Department of Philosophy

DOI: 10.20901/an.12.03

University of Rijeka

E-mail: ebaccarini@ffri.hr

\begin{abstract}
The paper is dedicated to replies to Christiano's criticism of Rawlsian public reason. Although Christiano's criticism is successful in relation to one possible interpretation of the public reason view, a better and more fructuous interpretation of the public reason view is at the disposition of the Rawlsian project. This view of public reason is deliberately an idealization. It shows how public justification would function in a well-ordered society where citizens are committed to liberal values. The shared reasons relevant for public justification are represented by the ideal of society as a fair system of cooperation between free and equal citizens, as well as by the three features of the liberal conceptions of justice (basic rights and liberties, their priority, and the means to use them). In virtue of this view of public reason, it avoids Christiano's objection of the utopianism of shared reasons, and it replies to the inequality argument, as well as to the generality and vagueness objection, and the inconsistency argument. The advantages of the proposal in the view of public reason, in comparison to Christiano's proceduralist democratic proposal, are shown in the reply to the inequality argument.
\end{abstract}

Keywords Christiano, democracy, public reason, Quong, Rawls

1. It is a pleasure and an honour to have the opportunity to discuss the influential democratic proposal of Thomas Christiano. I focus my discussion on his sophisticated criticism of Rawlsian public reason. Public reason is the view that says that the justification of laws and policies must not be based on controversial doctrines. The public reason view is explained by John Rawls' principle of legitimacy. 
Our exercise of political power is fully proper only when it is exercised in accordance with a constitution, the essentials of which all citizens as free and equal may reasonably be expected to endorse in the light of principles and ideals acceptable to their common human reason (Rawls, 1993/2005: 137).

I do not agree with the restriction of the requirement of providing justification based on public reasons only for constitutional essentials and the basic principles of justice, as in the Rawlsian quotation shown above. Like Quong's (Quong, 2011: 273-289) my view is that the justification for public reason must extend all the way to laws and public policies. This is the reason why I will use expressions like the "justification of laws" and not the "justification of constitutional essentials." I have explained my reasons for such an extended use of public reason elsewhere (Baccarini, 2015: 14), and I do not discuss the question here.

The intention of public reason is to protect free and equal citizenship in a society as a fair system of cooperation. Public reason contributes to this by requiring that the justification of laws is addressed to others, which means that laws are not justified by sectarian reasons, but only by reasons that all properly qualified citizens can reasonably accept.

In my view, Christiano is successful in criticizing one possible (and, perhaps, dominant) interpretation of the public reason view. However, I think that there is a better and more fructuous interpretation of the public reason view at the disposition of the Rawlsian project. It seems that Christiano assumes as his critical target a model of public reason that operates in the real world as it actually is. Public reason, thus interpreted, must be able to accommodate with real world subjects, and with their real world commitments. From this, it comes the criticism of the impossibility to realize the program, because the needed consensus about shared reasons can only be utopian.

Alternatively, there is a view of public reason that is deliberately an idealization. This view is not focused on the public justification of laws in the actual real world. It shows how public justification would function in a well-ordered society where citizens were committed to liberal values.

The view that I endorse is strongly influenced by the proposal of Jonathan Quong (Quong, 2011; Quong, 2012a; Quong, 2012b). In coherence with his view, the Rawlsian proposals' mistake, which opens the space for criticism, is to avoid assuming at the beginning of the process of constituting publicly justified laws and public policies, that all citizens would endorse the values or ideals of a well-ordered liberal society, as the basis of public reasoning in such a society (Quong, 2012a: 4). Importantly, in Quong's public reason view,

we do not begin with a commitment to public justification, and then only accept or endorse subsequent principles once we are satisfied they meet the test of public reason. Rather, we begin with certain fairly substantive commitments - to the idea of persons as free and equal, to a view of society as a fair system of cooperation, and to the fact of reasonable pluralism - and these commitments lead us to understand that a certain subset of our moral rules must meet the test of public reason if they are to have normative authority over those whom they purport to bind (Quong, 2012b: 56). 
The mistake is to think that public justification must be provided to people who do not already accept the basic tenets of a liberal conception of justice. Instead, the basic tenets of justice must be endorsed at the first stage of the justificatory process. They, thus, constitute the public reasons endorsed in public justification. The rationale for this picture of public justification is to show what public justification in a well ordered liberal society looks like, and it is well explained by Quong, who exclaims that the aim of employing public reason "is to understand how liberal theory can be made internally coherent" (Quong, 2011: 180).

However, something needs to be added to the general ideal that Quong puts at the justificatory basis of public reason in order to render the proposal effective. In my view, at the first justificatory level, we must put, together with the general ideal of society as a fair system of cooperation among free and equal citizens, a substantive specification of this ideal, as well. In other words, we must include the three main features of all eligible views of justice: certain basic rights and liberties, their priority, and the means to make use of them (Rawls, 1993/2005: 6). Together with the idea of society as a fair system of cooperation among free and equal citizens, they constitute the basis of justification in a well-ordered society.

Contrary to this view, Quong puts at the first stage only the most general ideal. Its role, then, is to justify the three main features (Quong, 2011: 174-189). But, there is no guarantee that the ideal can realize this goal. For example, an alternative, more or merely, proceduralist conclusion might be derived from it. The ideal of society as a fair system of cooperation may be interpreted as giving justification to an equal status in the procedure of decision making. Again, there is no guarantee that liberal principles of justice will result from this procedural framework. Procedural alternatives are only contingently, and in favorable conditions, related to the protections of basic liberties and social rights.

The inclusion of the three main features of liberal conceptions of justice in the first stage might appear as ad hoc, but this is not the case in discussion with Quong (and, I show bellow, in discussion with Christiano, as well). It is coherent with, moreover a better realization of, Quong's intention of rendering safe some substantive liberal rights, and not leaving them to justificatory accidents (Quong. 2012: 55), like what can happen if we interpret the general ideal in a procedural way. Procedural interpretations of free and equal citizenship, can interpret citizens as free and equal only in the process of the justification of prescriptions, but there are no guarantees that the results of procedures will be substantial, basic liberties and social rights.

The plan of the next part of the paper is (i) to describe Christiano's proposal and, in particular, his criticism of public reason, and (ii) to show why this criticism does not apply to the view of public reason that I endorse. I compare the merits of Christiano's theory and the public reason view. Christiano's proposal does not have advantages over the public reason proposal, at least interpreted as in the view that I embrace. I sketch the advantages of this public reason proposal, as well.

2. In Christiano's view, the arguments and reasons related to all epistemologically reasonable worldviews can be used in the process of public deliberation (Christiano, 2008: 202-230). Thus, each advances what she thinks is the 
epistemologically most reasonable doctrine, and the verdict is established by majoritarian vote. This is clearly opposed to the Rawlsian view that admits only some kind of shared reasons as justificatory. In Christiano's terminology, he defends the wide conception of public deliberation in opposition to the Rawlsian narrow conception of public deliberation that, in fact, is the public reason view. The narrow view is ruled by a principle that Rawlsians call reasonableness, or reciprocity. The quotation at the beginning of the paper is Rawls's explanation of the principle of reasonableness, or reciprocity.

Christiano exemplifies the theory of justice that he criticizes with Joshua Cohen's defence of the Rawlsian principle of reasonableness. I do not discuss directly Cohen's proposal, nor do I enter into the interpretative issues of his theory. My intention is to discuss Christiano's criticism of public reason and to indicate that there is a version of public reason that avoids his criticisms.

In the position that Christiano criticizes, citizens are defined as free and equal in a moderately procedural way, i.e., primarily by having in mind the fact that no decision can be unfairly imposed on them and no comprehensive doctrine can be imposed to them. In other words, the primary component of free and equal citizenship is constituted by not imposing on some citizens laws for which these citizens do not have justification, and ensuring for all of them a procedurally fair condition in the process of decision-making. Such a view of free and equal citizenship is well represented in quotations like:

To say that citizens are free is to say, inter alia, that no comprehensive moral or religious view provides a defining condition of membership or the foundation of the authorization to exercise political power (Cohen, 2009: 231)

and

The participants are substantively equal in that the existing distribution of power and resources does not shape their chances to contribute to deliberation (Cohen, 1997: 397).

This is the basis that leads to the shared reasons view of justification: no view on which there is disagreement can serve as a justification of laws and public policies, and, thus, only shared reasons can be employed. Obviously, there is optimism about the possibility of such shared reasons. Such optimism is the main target of Christiano's critique.

Christiano criticizes the shared reasons requirement, and his question is: "why must we refrain from proposing terms of association on the basis of reasons that we believe to be true or appropriate considerations but that we know to be incompatible with the reasonable comprehensive doctrines others accept?" (Christiano, 2008: 206). I discuss Christiano's critique of only one of Cohen's arguments, the democratic argument (Christiano, 2008: 222-230). The reason is that it is in relation to this argument that Christiano most clearly pictures his alternative to the Rawlsian proposal, and the most relevant reasons in favor of his alternative to the Rawlsian view.

This choice of argument that I discuss is related, also, to my intention, not to defend Cohen's proposal, nor to engage in its interpretation, but to show that it is possible to offer a formulation of public reason that resists Christiano's critical arguments.

The key idea of Cohen's democratic argument is that in order to treat individuals as free and equal in conditions of 
reasonable pluralism, power must be exercised on shared reasons, because passing laws that one can reasonably reject means treating her as inferior.

Christiano denies that the majority that passes laws in conformity to what they take as the epistemologically most reasonable view, and refuses what the other side sees as the epistemologically most reasonable view, is treating the members of the minority as inferiors. “The citizens' views concerning the issue at hand are being treated as less reasonable than the ideas the majority is acting on. But this is not the same as saying that the citizens are being treated as inferiors" (Christiano, 2008: 224). In the wide view of the democratic process, citizens are treated as equals, because each person's interests and capacities are taken into account properly, and because each person is listened to carefully and conscientiously, to each person arguments are offered conscientiously, and the verdict is based on the better judgment. Thus, there is not a case against the wide view of democracy from the standpoint of equality. It is not disrespectful of people's equality to make decisions on the basis of reasons that some can reasonably reject, provided it is made in a democratic context where each person can advance her views in a fair condition. If this condition is satisfied, then everybody is treated as equal.

To the extent that citizens have equal votes, equal resources with which to negotiate with others and equal resources with which to participate in the process of discussion and debate over principles, and to the extent that citizens are willing to listen to their fellow citizens with an open mind and willing to take everyone's interests equally into account when making democratic decisions, they are treating each other as equals [...] as much as can be done in a society where people disagree (Christiano, 2008: 229).

This is the most that can be done to treat people as equals in the democratic process. The public reason model, to fulfill its criterion (justification based on reasons that each part can reasonably accept), needs a utopian consensus for sufficient reasons. In the absence of such consensus, insisting on some specific reasons as the only legitimate justificatory reasons means not being loyal to the basic idea of Rawlsian reasonableness. On the other hand, decisions must be taken even if they are opposed to the justificatory reasons of some. But, then, the public reason model creates an impasse. It is the wide view of democracy that represents the realistic way out of this impasse, respectful of equality, as much as such is possible in a plural world.

An additional interest is realized by the wide view, as well, in this condition: the interest of feeling at home in the world. No more than protecting equality in the democratic process can be done for the interest of feeling at home in the world. The reason is, again, related to the deliberative impasse indicated above. In the case of deep pluralism, in order to respect others' interests of feeling at home in the wolrd, one must sacrifice this interest for herself. The conclusion is that

in a pluralistic society or indeed any moderately complex society, no one is fully at home in their world. This is what gives a point to the principle of equality: since there are conflicts of interests including the interest in being at home in the world, we want to structure the world so that each person's interest in being at home in 
the world is advanced equally. And democracy gives us a publicly clear way to do just that (Christiano, 2008, 229).

Another objection that Christiano addresses to the Rawlsian view is that the bases of Rawls's public reasons (like the idea of free and equal citizens) are so general that diverse citizens can accept them it in the general formulation, but they can strongly disagree on the specific interpretation. Thus, they do not have a common justificatory basis. Think about the libertarian view of freedom, as opposed to Rawls's view of free citizenship. Both assume free citizenship as a basic value, but the interpretation of the value is radically different. Thus, we do not have shared justificatory reasons even if general formulations are shared (Christiano, 1997: 267-271). If the Rawlsian view is enforced, this is an imposition over the libertarian (if the principle of legitimacy of laws is that they be enforced only if they are justified to all in virtue of the mere overlap of actual beliefs).

An argument related to those seen above that Christiano offers against the shared reasons' view of justification is that "we have reason to think that the principle of reasonableness [Rawls's liberal principle of legitimacy] is inegalitarian" (Christiano, 2008: 229). The reason, he says, is that it puts those people who would base public justification on other values and not only on shared reasons in an unequal position. The inequality is represented by not allowing some people to employ the justification of laws or public policies related to what they see as the best reasons. People who accept the justificatory supremacy of public values (i.e. society as a fair system of cooperation among free and equal citizens, as well as features of the family of liberal conceptions of justice that includes a list of basic liberties and rights, their priority, and resources to use them) are privileged. Others may either endorse different reasons in an alternative to those endorsed by Rawlsians, or other reasons that are potentially in competition and potentially have supremacy over the Rawlsian values. Requiring that all justification must be based only on shared reasons is discriminatory toward these people.

The last of Christiano's criticisms of public reason that I show is related to the fact that for the public reason proposal it is not indispensable that citizens agree about conclusions. Although reasons for the normative conclusions are shared, there may be divergences on their relative weight and on their interpretation. Such divergences are resolved by democratic decision. But, then, Christiano objects to Rawlsians when they introduce the criterion of voting as the solution to an absence of consensus. He says that in this way they introduce a concept different from the criterion of legitimacy that they generally endorse. Majority voting is a criterion of legitimacy that finds its legitimacy by virtue of treating all as equals in the procedure of decision making. The criterion of legitimacy is that each citizen has an equal say in the decision making process. But it allows making decisions even if they are not justified (i.e., supported by sufficient reasons) for some, which is in opposition to the legitimacy criterion of public reason. The problem, now appears to be that either decisions made by majority voting are not legitimate (because the decision is not justified for some), or the criterion based on the liberal principle of legitimacy is not needed, because majority voting is able to do the job (Christiano, 1997: 264-266). 
3.1. In order to reply to Christiano's proposal, it is important to endorse a concept of public reason that is substantial, i.e., it is not intended to protect citizens as free and equal only when they choose laws by placing them in a procedural position symmetrical to that of others by the resource of the shared reasons' justificatory requirement. The Rawlsian view (in the version that I embrace) does not ground legitimacy merely on the general persuasiveness of the reasons for a law. The reasons that matter are not those that are generally persuasive, nor related merely to procedural fairness, but those that are substantively constitutive of the ideal of free and equal citizenship in a society as a fair system of cooperation.

To the objection that this ideal is vague, the Rawlsian reply is that there is a compelling specification of this broad ideal. It goes together with citizens' basic rights, liberties and opportunities, their priority, as well as the resources to use them (Rawls, 1993/2005: 6). These are the three features of all reasonable (in Rawls's sense) conceptions of justice. They function as valid public reasons. These are values to which we must appeal when we address justification to our fellow citizens as free and equal, and we must ground public justification on them.

Grounding all public justification on such reasons and on reasons derivative from them in addition to a formal procedure that, in some way, ensures an equal say in the decision making procedure, or, perhaps, as a corrective of this procedure, is motivated by the intention to avoid legislation that substantially treats citizens as not free and less than equal. This is justified, because procedural equality is not the only component of the conception of equality. Even in a process of democratic decision making that respects the conditions that Christiano lists ("citizens have equal votes, equal resources with which to negotiate with others and equal resources with which to participate in the process of discussion and debate over principles, [...] citizens are willing to listen to their fellow citizens with an open mind and willing to take everyone's interests equally into account when making democratic decisions") infringements of basic rights and liberties, or social and democratic and social rights are possible in a decisional process where the justifications of decisions are fully left to participants. ${ }^{1}$ Christiano is aware of this, and for this reason he indicates components of equality that are not exhausted by procedural equality, as I show above.

3.2. The interpretation of the Rawlsian view, according to which the justificatory reasons are not merely the empirical overlapping consensus of the doctrines of people who compose the political society, but reasons that idealized citizens address to each other as free and equal by having in mind a substantial view of freedom and equality, helps to avoid Christiano's criticism of Cohen's democratic argument. The main basis for Christiano's criticism of the public reason project is that public reason is necessarily not loyal to itself. It requires a utopian consensus about shared reasons, and, in the absence of such consensus, it is impossible to address justification as interpreted by public reason to all citizens, and, thus, the condition of re-

1 To be sure, we do not have real evidence that this would really happen, because it is difficult to think that there has been any democratic deliberation that satisfies Christiano's demanding constraints in a wide scale society, and, thus, there is no evidence to disprove his claim. 
specting fellow citizens as free and equal is not satisfied.

The objection is avoided, because public reason does not address justification to real life citizens, but to idealized citizens, i.e., to reasonable citizens who already endorse a substantial view of free and equal citizenship.

Here, the difference between the public reason view that Christiano criticizes, and the one that I embrace is clear. In the former view, freedom and equality are harmed when decisions are made on the basis of reasons that some reject. The view that I endorse is more substantial. Free and equal citizenship is harmed when decisions are made on the basis of a justification that neglects substantial components of freedom and equality. This interpretation of public reason, that renders public reason requirements more substantial than the alternative interpretation endorsed so far, avoids the objections described above. The interpretation of public justification that I put forward here avoids the indicated criticism, because it requires only acceptability in virtue of the reasons that are such from the idealized perspective of citizens as substantially free and equal. It is not needed to successfully address justification to real life people who do not endorse basic liberties, and democratic and social rights. As a consequence, it is not true that the program is not loyal to itself.

Importantly, even if Christiano affirms the defense of procedural equality, he is aware of the risk that substantial components of public equality can be harmed in the democratic process. This is why he declares some liberal rights (freedom of conscience, freedom of personal pursuit, freedom of association, freedom of expression, basic personal property, fair trial and to be treated in accordance with due process of law) and democratic rights as limits on democratic authority.

There are reasonably clear limits to the authority of democracy and they can be derived from the same principle of public equality that underlies democratic authority (Christiano, 2008: 260).

A guaranteed economic minimum and not being permanently outvoted sensibly weaken the authority of democracy.

All these values are part of what constitutes public equality, the same as democratic rights, and this is the reason why they can put limits to, or, at least, weaken the authority of democracy (Christiano, 2008: 260-300).

This is clearl an important point. For Christiano, as well as in the view of public reason that I endorse, procedural equality in a democratic process is not sufficient to protect substantial equality. Some values have normative authority prior to the responses of democratic process. This permits us to reject Christiano's inequality objection to public reason.

3.3. Remember that the inequality argument objects that public reason discriminates against citizens that do not share the egalitarian liberal values that public reason establishes as the sufficient justificatory standard of laws, because they embrace different values, or they embrace as equally important other values, potentially in competition with the values that Rawls takes as fundamental for public justification (Christiano, 2008: 229).

My reply is that the view of public justification that appeals to shared public reasons addressed to citizens as free and equal is no more inegalitarian, if we 
evaluate equality from this point of view, than Christiano's theory. To be sure, Christiano endorses the wide view of public deliberation, i.e., everybody is allowed to use all reasons that she finds to be the best reasons in the process of public justification. But, at the same time, he puts limits to the authority of democratic decision making.

What is the main difference between the Rawlsian and Christiano's position? Rawlsians protect liberal and egalitarian values by making them the exclusive reasons employed in public deliberation, while Christiano protects basic liberties, and social and democratic rights, from the authority of democracy by declaring them as limits to the democratic authority. Thus, there is no authority if a decision that abolishes the freedom of expression is made on the basis of a merely procedurally fair decision. For any decision, if some people complain about it and they appeal to the protected values (basic freedoms, economic minimum, etc.), then it is needed to defend the policy on exactly the terms of these values. Otherwise, the domain is exempt from democratic decision. At least, this is how I interpret Christiano's position.

Think about the possible example of pornography. An assembly deliberates on forbidding it. There is a complaint from the standpoint of freedom of expression. At this point, a reply is needed in order to show that the decision is not harmful towards the freedom of expression. If this is not done, the decision loses its authority.

In other words, in the case of complaints that appeal to protected values a defense is required that manages similar concepts to those that the Rawlsian perspective indicates as appropriate. Citizens are free to use all the reasons they find appropriate, but only until a com- plaint that appeals to the values protected from democratic deliberation is expressed. At this point, those people who are more skilled, or who prefer, to use liberal ideals and principles in public justification are in the advantage. Their justificatory resources function as trumps. In relation to the legitimacy of using a full set of reasons that different people want to use, Christiano is more generous in the course of the deliberative process, but, this advantage disappears, because he accepts as dominant reasons of the kind of Rawlsian public reasons at the end of the process, where some democratic and procedurally fair decisions can be found losing authority. ${ }^{2}$

Thus, the major difference between Christiano and Rawlsians in this debate does not consist in not constraining the democratic process, or putting some limits to the democratic process. There are limits to the democratic process on both sides. The relevant question is whether it is better to leave the use of reasons in the democratic debate uncontrolled, and, then, ensure basic liberal, social and democratic rights by denying authority to some democratic decisions that can be seen as damaging to these rights and liberties (apart if those who object to the exclusion are able to appeal to concepts that, broadly speaking, in their content correspond to Rawlsian public reasons), or it is better to regulate the process from the beginning, by admitting only justification based on reasons that citizens address to each other as substantively free and equal? In my view, the Rawlsian option has advantages.

2 Thanks to Kai Spiekermann for having helped me to formulate in this terminology the distinction between Rawls's and Christiano's view. 
In Christiano's model citizens appear to be tutored. They are free to debate and decide as they want, but not when there is a complaint that appeals to basic liberties, etc., if they are not able to use public reasons. In such a case they must simply accept that issues are settled without their participation. In the Rawlsian model, citizens, on the other hand, are limited in the reasons that they can employ, but they can deliberate on all issues. They do this by having in mind the reasons that are relevant for citizens who address to each other justification as substantially free and equal citizens. This has several important consequences. One is that, in this way, they become trained and more familiar with the values. The other one is that they are the protagonists of the creation of the society inspired by the values of freedom and equality among citizens. As the third virtue, I mention the ability to pre-empt injustices, instead of the need to repair them. ${ }^{3}$

This is particularly visible in one case that reduces the authority of democratic decisions: the permanent outvoting of persistent minorities. In such a case members of the persistent minority feel as alienated and as strangers in the world where they live. It appears that the interest of feeling at home in the world is threatened (Christiano, 2008: 288-292). This is avoided in the process of public justification by the public reason view of justification. We can find the explanation in Quong's discussion of the scope of public reason. In one of the examples of employing public reason outside the domain of constitutional essentials, he indicates there is the use of the public

3 Nebojsa Zelic remarks the role of public reason justification in shaping a community (Zelic, 2016). reason of fairness (Quong, 2011: 280281). Imagine a situation where in a town churches related to one religion have already been built. Members of another religion do not have any church in their town. The virtue of fairness that can be used in the deliberative process as a weighty public reason, at one point, indicates that the priority is that of building a church for the minority religion, if the question is to build a church. We can easily imagine several similar examples. In brief, the public reason of fairness is a resource to block, during public justification, the process in which a minority is permanently outvoted.

The appeal to fairness in this case will be more egalitarian in the results, for persistent minorities, than the principle that Christiano puts forward for limiting outvoting of persistent minorities, i.e. the minimum outcome standard. Fairness does not favor only a minimum of outcomes, but outcomes proportional to those for the majority.

This is not necessarily viewed as an advantage from all evaluative standpoints. But possibly there is an advantage for the Rawlsian view that might be perceived as such even from the democratic perspective of Christiano. The Rawlsian view clearly indicates where permanent outvoting is removed: in the process of public justification, i.e., during the qualified democratic process.

Where is the permanent outvoting of permanent minorities corrected in Christiano's view? One possibility is after the democratic process. This possibility is opposed to democracy as a feature of public equality and, thus, it would be better to find a different solution.

Alternatively, the permanent outvoting of a permanent minority is avoided during the democratic process. It is here that it is possible to appeal to the mini- 
mum outcome standard to interrupt permanent outvoting. But, in such a case, I do see where there is a difference with the employment of public reasons, like in the Rawlsian view of justification. The minimum outcome standard appears to function exactly like the principle of fairness in a Rawlsian process of justification.

3.4. Is this sectarian? That is, is it sectarian to pre-empt disrespecting basic rights and liberties in public deliberation by assuming specific justificatory reasons in the process of public justification (Gaus, 2012)? Importantly for the present debate, this is not an argument that Christiano can use in relation to the public reason view that I endorse. $\mathrm{He}$ assumes values and normative contents that are settled by the theoretician prior to the deliberative process of citizens, and not all citizens in the real world endorse these norms. To be sure, contrary to the public reason project, Christiano is engaged in justifying the values that constitute his conception of justice in a way that Quong would call external defense. But public reason is not incompatible with such an enterprise. Although the public reason project is not engaged in it (because it is engaged in a different stage of the debate, i.e., in the stage when public reasons are already settled and are employed for further justification), it can make use of such enterprises as a form of external justification for the public reasons employed. There is no motive as to why a public reason project might not use, for example, Christiano's defense of the substantial components of equality as such a resource. Alternatively, public reason can assume the basic values, and leave it to each person to find their justification (Quong, 2011: 188). Thus, a supporter of public reason can applaud Christiano's, and other authors' justifications of basic liberties, and social and democratic rights, and suggest to them that they abandon pure proceduralist democratic models, and endorse a public reason democratic model for further justification, after the basic values have been established and endorsed.

Still, there can be the objection that both the public reason view, even if it employs supportive theories (like Christiano's, and other liberal theories), is not sufficiently respectful of pluralism. There might be, and there are, epistemologically reasonable doctrines that oppose liberal values and ideals, at least as sufficient justificatory reasons. In such a case, I would be ready to accept that there are limits to the external justification of liberalism. At this point, two things can still be said in favor of the liberal conception of justice.

One is indicated by Brian Barry.

If the parties want peace enough to make the concessions that are needed to reduce their demands so that they become compatible, liberalism proposes a formula for doing so. More than that, liberal principles can make a moral appeal as a fair way of solving conflict, because they offer the parties equal treatment. There is, however, no guarantee that either peace or equity will be regarded by everybody as more important than winning (Barry, 2001: 25).

It seems to me reasonable to classify such people as unreasonable, and to exclude their reasons as legitimate reasons for political justification.

To all others, liberalism has something important to say. Although it is not a magic bullet in the course of history, it has proven to be successful as a way out from persistent conflicts, starting from those among Catholics and Protestants. 
Rival conceptions of justice can hardly demonstrate equivalent credentials. Liberal conceptions of justice have been the basis of those constitutions that have resulted from this process, i.e., the basic values of liberal conceptions of justice are the fundamental values of constitutional democracies. Thus, the public reason program can represent a project that shows what consistently living in accordance with these values would mean. The program would, thus, not be an example of sectarianism, but of coherence.

After all, it might be important to show that some political proposals that are not explicitly declared to be loyal to the basic values of constitutional democracies, may be revealed to be so.

3.5. The interpretation of public reason that I endorse helps to reply to Christiano's generality and vagueness objection, as well. The critique would be appropriate if the Rawlsian requirement were that laws must be simply justified to all in virtue of the reasons that they actually endorse. But this is not the most fruitful interpretation of the Rawlsian program. As I have said, it is more fructuous to interpret the Rawlsian program as promoting justification based on reasons that idealized citizens address each others as substantially free and equal. In the light of this project, we can classify some endorsements of values as justificatory reasons for laws and public policies as simply mistaken. Thus, in relation to Christiano's objection that, for example, the libertarian conception is a counter-example to the alleged overlapping consensus, the possible reply open to Rawlsians is simply to say that the libertarian interpretation of freedom as de- tached from equality is wrong. Actually, this is what Rawls says. Precisely, Rawls says that it is unreasonable (Rawls, 1993/2005: lvi; Rawls, 2001; 137-138). There are several ways to indicate that libertarianism is wrong, and Christiano has reliably indicated one of them (Christiano, 2008: 112-116). A supporter of the Rawlsian program can rely on these argumentations in order to exclude libertarianism from the eligible set of conceptions of justice.

3.6. I end the paper by discussing a further objection that Christiano addresses to the public reason view. It is the objection that Rawlsians cannot adopt democratic authority, and their criterion of justification, at the same time.

Again, I think that the particular interpretation of the Rawlsian project that I endorse helps to avoid the criticism. The basic criterion of legitimacy is that of providing justification on the basis of substantial reasons that citizens can address each other as free and equal. Once the debate is shaped by this constraint, we can expect that there will be disagreements that we must resolve by voting. However, it is important that voting appears only under such a condition, where the alternatives are all justified (although inconclusively, in the meaning of the concept in (Gaus, 1996: 151156) and (Williams, 2000)) on the basis of reasons that citizens can address each other as substantially free and equal. This guarantees that the result of voting will not harm anyone's status as a free and equal citizen. The two criteria of legitimacy (justification based on reasons that citizens can address to each other as free and equal, and majority vote) are not rivals, but complementary. 


\section{LITERATURE}

Baccarini, E. (2015) In A Better World. Public Reason and Biotechnologies. Rijeka: University of Rijeka, Faculty of Humanities and Social Sciences in Rijeka.

Barry, B. (2001) Culture and Equality. An Egalitarian Critique of Multiculturalism. Cambridge: Polity.

Cohen, J. (1999) Reflections on Habermas and Democracy. Ratio Juris (12) 4 : 385-416.

Cohen, J. (2009) Democracy and Liberty, in Cohen, J. Philosophy, Politics, Democracy. Cambridge, Mass.: Harvard University Press: 223-267.

Christiano, T. (1997) The Significance of Public Deliberation, in: Bohman, J., ur., Deliberative Democracy. Essays on Reason and Politics. Cambridge, Mass.: MIT., pp. 243-277.

Christiano, T. (2008) The Constitution of Equality. Democratic Authority and Its Limits. Oxford: Oxford University Press

Gaus, G. (1996): Justificatory Liberalism. An Essays on Epistemology and Political Theory. Oxford: Oxford University Press.
Gaus, G. (2012) Sectarianism without Perfection? Quong's Political Liberalism. Philosophy and Public Issues (2) 1: 7-15.

Quong, J. (2011): Liberalism without Perfection. Oxford: Oxford University Press.

Quong, J. (2012a): Liberalism without Perfection. A Précis by Jonathan Quong. Philosophy and Public Issues (2) 1: 1-6.

Quong, J. (2012b) Liberalism without Perfect. Replies to Gaus, Colburn, Chan, Bocchiola. Philosophy and Public Issues (2) 1: 51-79.

Rawls, J. (1993/2005) Political Liberalism. New York: Columbia University Press.

Rawls, J. (2001) Justice as Fairness. A Restatement. Cambridge, Mass: Harvard University Press.

Williams, A. (2000) The Alleged Incompleteness of Public Reason. Res Publica (6) 2: 199-211.

Zelic, N. (2015) Public Equality, Public Reason and Liberal Community. Anali hrvatskog politološkog društva / Annals of the Croatian Political Science Association (12) 1: 49-66. 


\section{Sloboda i jednakost u pluralističkom društvu. Pojašnjenje i obrana teorije javnoga uma}

SAŽETAK Članak je posvećen Chirstianovoj kritici Ralwsovog koncepta javnog uma. lako je Christianova kritika uspješna kada se radi o jednoj interpretaciji javnog uma, bolja i plodnija interpretacija javnog uma moguća je unutar Rawlsovog projekta. Ovakvo razumijevanje javnog uma počiva na namjernoj idealizaciji. Takva idealizacija pokazuje kako bi javno opravdanje funkcioniralo u dobro uređenom društvu gdje su građani predani liberalnim vrijednostima. Zajednički razlozi relevantni za javno opravdanje predstavljeni su u idealu društva kao pravičnog sustava kooperacije između slobodnih i jednakih građana, kao i u tri odrednice liberalne koncepcije pravednosti (temeljna prava i slobode, njihov prioritet, te način na koji se koriste). Ovakav pristup javnom umu izbjegava Christianov prigovor utopijskog karaktera zajedničkih razloga, te odgovara na argument nejednakosti, prigovor općenitosti, te argument nekonzistentnosti. U odgovoru na argument nejednakosti, pojašnjene su prednosti pristupa javnog uma nad Christianovim pristupom proceduralne demokracije.

KLJUČNE RIJEČI Christiano, demokracija, javni um, Quong, Rawls 